\title{
Research on the talents training mode of Higher Vocational Education
}

\author{
Jie $\mathrm{He}^{1, \text { a }}$, Wanzhong Qin ${ }^{2, b}$ \\ ${ }^{1}$ Tianjin Vocational Institute, Tianjin 300410, China \\ 2 Tianjin Vocational Institute, Tianjin 300410, China \\ ahejie1964@126.com, ${ }^{b}$ ginwanzhong1964@126.com
}

\begin{abstract}
Keywords: Higher vocational education. Talents training mode. Work-study combination. Problem and countermeasure

Abstract. Talents training mode is the standard form of talents training. The mode based on work-study combination is a popular way in vocational education all over the world. However there are some puzzlement and problems in the understanding of the higher vocational education talents training mode in China because of many concrete reasons. The paper tries to clarify the way of training high-level technical and skilled talents by analyzing the types and characteristics of the mode abroad and its situation in China and then exploring the measures for improve the mode.
\end{abstract}

\section{Introduction}

Entered in 21th century, the world's requirement for senior talents has changed remarkably and the international level of higher education is also rapidly improving. In recent years, China's higher education management system reform and teaching reform have entered deep water, teaching quality problems have increasingly attracted the attention of government, colleges and universities, enterprises and society. As an important part of higher education, higher vocational education has developed rapidly in recent years. The government issued many files to indicate the reform and pointed out that higher vocational education shoulders the mission of training high skilled talents for production, construction, service and management in forward position ${ }^{[1]}$. The training mode of school-enterprise cooperation and work-study combination should be vigorously promoted ${ }^{[2]}$. Facing the great change of social and economic in domestic and international, it is necessary to compare and study higher vocational education talents training mode of China and abroad and use the foreign advanced experience for reference to construct higher vocational education talent training model with Chinese characteristics, in order to promote the further improvement of the teaching quality of higher vocational education in China and training mass of high level technical and skilled talents for China's modernization construction.

\section{The current situation of higher vocational education talents training mode in abroad}

There are dozens of explanations about talents training mode because of the different understanding around the "talents training" and "model". Talent cultivation is composed of three factors which are man do training, training measures and training target. The term "mode" refers to the standard form of some kind of thing or the standard style that the person can follow. Therefore, the "talent training model" is the standard form of talents training or talents training standard style that people can follow and its contents involve two aspects of talents training objectives and talents training measures.

Combination of engineering talent cultivation mode is to students as the main object, application ability training as the main line, on humanistic quality and professional quality culture based, adhere to walk training objectives and the needs of the enterprise, combining culture combined with the working process and, combining training regimen and double certificate path, in order to maximize the development of the students' practical ability, innovation ability, entrepreneurial ability and professional extension ability as the goal, to improve the students' professional ability and comprehensive quality, adapt to the social demand for talents. 
Since the 70's of the 20th century, higher vocational education has been developing vigorously in the developed countries, and they started also early in the institutions setting, organization and management, theory, methods and ways about talents training mode research and development. They have formed a number of distinctive higher vocational education talents training modes which typically as the following four. (1)Dual-system mode(used in Germany). The characteristics are that take enterprise as the main body in the organization system of running school; take professional ability as the standard of the training mode; take market and social demand as the guide of the operation mechanism. (2)CBE mode (Competency Based Education, used in Canada and the United states). The characteristic are that training objectives is objective and clear; teaching content closely contact training objectives; flexible and diverse forms of teaching; pay attention to objective evaluation of skills. (3)CBET mode (Competency-Based Education and Training, used in Britain and Australia). The characteristics are that the teaching is based on the ability of the students but not on the learning time; it is the individualized teaching to adapt to the individual differences of students; it is a kind of flexible and open teaching. (4)MES mode (Modules of Employable Skill, developed by International Labor Organization). The characteristics are that take the vocational training as a system; each skill module which for a job or post consist of several units; students learn a unit will be able to master a skill and learn a module will be able to master a set of skills; take skill training as the core, take students as the center, take students self-study as main method.

Analysis these foreign talents training mode, we can found that they have the following characteristics: one is that take the professional ability requirements as the goal and the teaching guiding ideology which " take professional ability as center" formed; the second is that the curriculum development based on ability standard which formulated by the practice experts; the third is that talents training based on production-study combination. These characteristics can solve the problem that the talents meet the requirements of the employing units and very worthy of our reference. But they also exist problems that the professional post targeted too narrow and difficult to adapt to the situation which the rapid development of science and technology.

\section{The current situation of higher vocational education talents training mode in China}

China's higher vocational education began in 1980s, but the talent training mode was gradually being concerned in the 90's, and began to prevail in 21th Century. Yi Zu Gong in his book "on the university talents training mode" for the first time systematically expound the concept and specific elements on talent training mode in theory, and initial establishment the research framework of higher vocational education. Xinxiang Lv in the book "the higher vocational technical education " enhance higher vocational education talents training mode to the theoretical level, systematically studied elements of the talents training mode which including training objectives, professional setting, curriculum mode and so on, and initial constructed the higher vocational education talents training mode of in China. And then a series of books issued which introduce advanced talents training mode abroad. Many higher vocational colleges actively explore and practice higher vocational education talents training mode and formed modes with them-self characteristics and the typical examples as follow. (1)"Sandwich" mode. The characteristics are that outstanding ability to work as the center of teaching; training compound talent with "multi abilities"; implementation "sandwich" talents training mode which theoretical study, skills training and field practice combined. (2)"one main two auxiliary, a fine multi ability" mode. The characteristics are that deepening the application type talents training methods and ways, meet the graduates needs to adapt to the social competition; emphasize the application type talents training should also have characteristics of extroversion type and compound type; to realize the organic unity of knowledge, ability and quality training; showing the cultivation of students' innovative spirit. (3)"Ability center" model. The characteristics are that take ability as the center to develop teaching plans; does not require the system and integrity of theoretical knowledge but stressed the comprehensive and practical; graduates practical ability can quickly adapt to the job. 
(4) "production-study cooperation education" mode. The characteristics are that school-enterprise together develop teaching plans; combination of education with production and labor, implementation of the enterprises and schools "double control", "modular" structure in the course; combination of full-time and part-time teachers, combination of both internal and external training base; school-enterprise common assessment to got double certificate.

Overview of China and foreign higher vocational education personnel training mode can be found: the modes break through the traditional with subject system training mode and generally emphasize the importance of practice teaching, so that higher vocational education is more close to the actual production and reflecting the characteristics of applied talents training. Different talents training mode has the different fitting scope and corresponding implementation conditions and their defects, does not exist the so-called "best mode". So, in order to achieve the best effect of education, we must integrate variety of modes according to the time and place. When we in profits from the foreign talents training mode can't completely copy but must take into account China's national conditions.

All in all, the higher vocational education talent training mode has its unique advantages in training applied talents. For our country, because of the requirement of social economic development and the talents quality promotion, the talents training mode has been paid more and more attention. The first, China's talents training mode updates faster with the development of economy and various modes stream in an endless. The training subjects involve the higher vocational colleges, enterprises, government and social organizations, but most only consider the colleges and enterprises to research. Secondly, the mode is generally on the improvement of foreign advanced mode or autonomous exploration achievements. Although the modes have certain guidance significance for talents training in China, but the modes may not apply or operability is not so good in China's economic structure and industrial organization. Finally, have not sufficient study on the talents training mode theory and practice, and lead to many advanced theory can not be apply to practice. So we need put forward the measures to improve the mode based on using the advanced experience and theory of other countries for reference, combining with China's industrial structure, employment structure and economic structure, using the theory of system to in-depth study the function and effect of the government, social organizations, enterprises and colleges.

\section{The main problems of higher vocational education talents training mode}

In the key period of the transformation and development of higher vocational education in China, some key problems in the mode of talent training have emerged, which has become an important resistance to the development of higher vocational Education.

Research on the theory of talents training mode lagging. On the one hand, Chinese higher vocational education started late, history is short, the foundation is relatively weak, as a "type" of higher vocational education is still in the early stages of development. On the other hand, lack of scientific and systematic and specialized research institutions, and the research team is still very weak. Therefore make the theoretical research of higher vocational education in China there is still a big gap compared with foreign country, lead to the practitioner of China's higher vocational education talents training mode lack of systematic and scientific theory guidance ${ }^{[3]}$.

The enthusiasm of enterprises to participate in talents training is not high. At present, China's higher vocational education work-study combination and school-enterprise cooperation situation is "the school is hot, the enterprise is cold". The reason is that the school education environment and enterprise production environment, the social benefits of school and the economic benefits of enterprises can not be organic combine. The main position and the interest demands of the Enterprises can not be reflected in the school-enterprise cooperation. The school culture value orientation is different from enterprise culture value orientation. Especially the government lack of tax preferential policy and system security to the enterprises which participate in the school-enterprise cooperation, and the country have not clear the system requirements to participate in work-study combination and school-enterprise cooperation, and the organization and coordination and social 
security system is not perfect. The dynamic mechanism of school-enterprise cooperation is not established and the enterprises combined the school-enterprise cooperation is only "spontaneous civil behavior".

Higher vocational college is difficult to effectively implement the talents training mode. Due to the higher vocational education in our country is still in the continuous development and improvement stage, Many colleges exist problems such as lack of strength of scientific research, lack of "engineer-teacher type" teachers, lack of practice teaching means, school funding shortages, training equipment backward and so on, so it is difficult to form complementary cooperation advantages relative to enterprises. Vocational colleges attempt to rely on cooperating with enterprises to solve teaching problems and wishful thinking to unilaterally require enterprises to serve the school, but it is lack of research and solutions ability of solve the problem which enterprises in urgent need to. Due to lack of cooperation foundation of "complementary advantages, mutual benefit and common development", so the strength of higher vocational colleges is difficult to form an effective driving force for the work-study combination.

Lack of the legal system to protect the implementation of talents training mode. The important reasons for the success of the German "dual system", the American "cooperative education" and the Japan "official-production-study" is the establishment of a complete vocational education legal protection system. On the one hand, the German government has promulgated the 10 macro vocational education laws and regulations from the 50's of the 20th century; on the other hand, Germany departments, industries, local also unveiled specific regulations or implementation method to ensure the sustaining and healthy development of the vocational education. The formulation of laws and regulations about vocational education is relatively lagging behind in China. On the one hand, in addition to the "occupation education law" etc. several of the macro laws, the country or local almost without any specific laws and regulations, resulting in higher vocational colleges work-study combination and school-enterprise cooperation combined lack of perfect policies and regulations guarantee, Lack of a sound system of organization and coordination and safeguard. On the other hand, the current "occupation education law" have regulating to schools and enterprises, but focuses more on their responsibilities and obligations, and the binding on responsibilities is still very weak, and in consideration of its rights and interests are not enough.

The support system of talent training model is not perfect. In education, we lack the support of management system, personnel structure, teaching system, curriculum system and so on. Most of the school management power is relatively weak, generally by the teaching management department. In terms of personnel structure, it is difficult to have a engineer-teacher structure management team. In the teaching system, there is no mature "full credit system" and "flexible credit system", the students' independent choice is limited. In terms of curriculum, it is not completely take social practice as a required course. The country file clearly pointed out: to establish and perfect the college running mechanism of government led, industry guidance, enterprises to participate, develop school-enterprise cooperation regulations, promote the school-enterprise cooperation institutionalize $^{[4]}$. But in the actual operation process, the local sponsor, industry sponsor and private sponsor higher vocational colleges directly or indirectly accept the leading of the country, provincial, municipal, industry, enterprise. Long leadership, pluralism organization system and multi-level operating mechanism makes our country higher vocational colleges exist contradictions between internal management system and operation mechanism and external management system and operational mechanism, so unable to effectively coordinate.

The absence of government behavior in talents training mode. The functions of government assume vocational education is very clear and acting very active in Germany, America and Japan. Vocational education is the pillar of economic development in Germany, the government's main responsibility is to supervise and inspect the vocational education law's implementation situation of industry enterprises and schools, and reward or punishment them. The integration of production-study-research is the basic state policy of vocational education in Japan, and the government plays a guiding and leading role in the joint body of official-production-study. One of the 
important reasons for the success of American vocational education is that governments at various levels, such as the country and state and so on, give full play to their functions and promote the development of cooperative education. In our country, on the one hand, because there is no a clear regulations to constrain government's behavior and function in work-study combination and school-enterprise cooperation, so work-study combination has often been regarded as something outside of government behavior and responsibilities. On the other hand, the government to the mechanism construction about enterprise participation higher vocational college work-study combination is still stuck in the macro management and propaganda, lack of necessary guarantee in legal and policy and institutional, lack of participate and inspection and supervision to work-study combination and school-enterprise cooperation ${ }^{[5]}$.

\section{Measures of optimization the higher vocational education talents training mode}

Systematic of talents training mode theory study. At present, the organizations engaged in the institutions of higher vocational education can be divided into four types in China.These research institutes are fragmented, research level is uneven, the theoretical research on Chinese vocational education lack of the deep and systematic exploration and explained. Therefore should be integrate the important resources and the academic power, draw lessons from foreign advanced theories and experience, starting monographic study on the major issues for example China's higher vocational education theory, and forming a comprehensive and systematic achievements about talent training theory, to provide theoretical support and practical guidance for China's higher vocational education, gradually building vocational education theory system that accord with China's actual. At the same time, increase the training of higher vocational education research personnel, to improve the talents training theory research and professional development overall level of China's higher vocational education.

Pay attention to the main status of enterprises in the talents training mode implement. In China's higher vocational education, the main reason of enterprises are not interested in participate work-study combination is that the enterprise's main body position is not obvious and the interests of the enterprise can't be realized. Therefore, on the one hand, use the system constraints and system security to reflect the main body status of enterprises such as legal person main body, market main body, the investment main body, risk-taking subject and benefits distribution main body and so on. On the other hand, should be build a power driven mechanism, benefit balance mechanism, reward excitation mechanism and communication-coordination mechanism to ensure that the legitimate economic interests and the interests of urgent need for the employees of enterprises in school-enterprise cooperation.

To enhance the strength of higher vocational colleges talents training. The work-study relationship between higher vocational education and enterprise is dialectical. The higher vocational education is to cultivate talents and provide services to promote enterprise development, and the development of enterprises will promote the development of education. To strengthen the work-study combination depends on the needs of both the enterprise and the school, especially the demand of the enterprise is very important. At present, the experimental training conditions and scientific research ability of higher vocational colleges are weak generally, therefore, it is essential to strengthen the construction of the basic conditions of higher vocational talents training. Vocational colleges should rely on the industry, take the initiative to fight for the support of industry sectors, and strive for enterprises strengthening cooperation with schools in the equipment, facilities, technical experts, out school training base and other aspects.

Form the regulatory system of implementation talents training mode. To revise the "Vocational Education Law" on the basis of the "Education Planning Outline" as soon as possible and formulate relevant laws and regulations, to support enterprises which participate in and support higher vocational education development such as tax relief, improve industry, product updates, government awards, preferential policies and so on. To promulgate "vocational education school-enterprise 
cooperation promotion way" as soon as possible, for making clear the responsibility, rights and obligations of the government, enterprises and schools in wore-study combination and school-enterprise cooperation. Province and municipality government should develop relevant implement regulations or rules by combining the local actual and industry characteristics to strengthen the practicability and operational of relevant laws. Gradually improve the legal system for the development of higher vocational education.

Improve the system and operation mechanism of higher vocational education. To establish the institutional guarantee system which adapt to the higher vocational education talents training mode operation, reflecting the characteristics that take service as the purpose, employment oriented, adopt the development road of work-study combination. Strengthen the work-study combination to train high level technical-skilled talents, not only to perfect teaching management system, student management system, teaching quality evaluation system, students comprehensive quality evaluation system, student practice-training assessment system, also improving teacher hiring and training system, distribution of part-time teachers employment system, distribution incentive system, financial system and other system. The system of running the school and operation mechanism should be guided and supervised by the board of directors. To implement the deep, high level, close type schools-enterprises cooperation mode based on enterprise's main body, the school leadership, for improve the quality and efficiency of higher vocational education school-enterprise cooperation.

To give full play to the role of the government. Clear the legal responsibility and legal obligation of central, provincial and municipal levels of government in higher vocational education talents training mode implementation. Clear the government's legal responsibility and increase the penalty clauses in current "Vocational Education Law". Perfect the management system and working mechanism of higher vocational education work-study combination and school-enterprises combined, strengthen the government planning and coordinating role, so as to make the management system more reasonable, operation mechanism more flexible, safeguard mechanism more effective

\section{Acknowledgements}

This work was financially supported by the Tianjin 2015 philosophy and social science planning project (project Number: TJJX15-030).

\section{References}

[1] Ministry of Education: Ideas about Overall Improve Higher Vocational Education Quality (People's Press, China 2006). (In Chinese)

[2] The State Council: The Decision about Devote Major Efforts to Develop Vocational Education (People's Press, China 2005). (In Chinese)

[3] Z.M. Song. Journal of Guangdong Technology Normal College: Vocational Education, Vol. 22(2010), No.1, p.36. (In Chinese)

[4] Ministry of Education. The Mid-long-term Program of The State Education Reform and Development (2010-2020) (People's Press, China 2007). (In Chinese)

[5] J.M. Ye, N.S. Liang, X.H. China Higher Education Research, Vol. 25(2011), No.12, p.72. (In Chinese) 